\title{
RADIOCARBON IN ANNUAL TREE RINGS FROM THAILAND DURING THE PRE-BOMB PERIOD, AD 1938-1954
}

\author{
Quan Hua ${ }^{1,2} \cdot$ Mike Barbetti $^{3}$ Ugo Zoppi ${ }^{1}$ \\ ABSTRACT. Annual tree rings from Thailand were analyzed by radiocarbon AMS for AD 1938-1954. The results showed \\ no significant depletion in atmospheric ${ }^{14} \mathrm{C}$ over Thailand during the pre-bomb period, even though the air mass to Thailand \\ during the growing season of tree rings is transported over a potentially significant source of oceanic ${ }^{14} \mathrm{C}$-depleted $\mathrm{CO}_{2}$, out- \\ gassing in the northern Indian Ocean. When compared with Washington and Chile for different periods from the 17th century \\ to AD 1954, Thailand appears to have the characteristics of Southern Hemisphere ${ }^{14} \mathrm{C}$. This supports our previous finding that \\ Thailand was strongly influenced by the entrainment of Southern Hemisphere air parcels in the southwest Asian monsoon \\ (Hua et al. 2004). For Thailand, this effect is much stronger than the reduction of atmospheric ${ }^{14} \mathrm{C}$ in association with $\mathrm{CO}_{2}$ out- \\ gassing in the northern Indian Ocean.
}

\section{INTRODUCTION}

In previous work on radiocarbon in annual tree rings from Thailand for the period AD 1952-1975 (Hua et al. 2000), we found a large depletion of ${ }^{14} \mathrm{C}$ for Thailand. This occurred in 1953 and 1954the period prior to the dominance of bomb ${ }^{14} \mathrm{C}$ in the atmosphere, which started in 1955 . We thought that this depletion over Thailand could be partly due to upwelling in the Indian Ocean between $20^{\circ} \mathrm{N}$ and $5^{\circ} \mathrm{S}$. This region is known for persistent upwelling, with excess partial pressure of $\mathrm{CO}_{2}$ reaching $30 \mu \mathrm{atm}$ (Keeling 1968; Takahashi et al. 1997) and a low $\Delta^{14} \mathrm{C}$ level of surface water $[\sim+100 \%$ for 1977-1978 compared with $\sim+140 \%$ at $30^{\circ} \mathrm{S}$ (Stuiver and Östlund 1983); $-50 \%$ to $-85 \%$ for 19 th to early 20th centuries derived from carbonate samples growing in the surface ocean (Dutta et al. 2001; Southon et al. 2002)]. This upwelling activity might provide a regional source of ${ }^{14} \mathrm{C}$-depleted $\mathrm{CO}_{2}$, which mixes with atmospheric $\mathrm{CO}_{2}$ and is transported over Thailand by the annual southwest monsoon. This phenomenon, a decrease of regional atmospheric ${ }^{14} \mathrm{C}$ in association with the upwelling activity of the oceans, is known for the North Pacific Ocean off the coast of Washington State (Damon et al. 1989).

In the present paper, we present a further investigation of this phenomenon for the period AD 1938-1951, using the same Pinus kesiya tree grown in northwestern Thailand $\left(19^{\circ} \mathrm{N}, 99^{\circ} \mathrm{E}\right)$. These data are needed for a better evaluation of the above hypothesis - a possible regional reduction of atmospheric ${ }^{14} \mathrm{C}$ in association with upwelling in the northern Indian Ocean.

\section{SAMPLE DESCRIPTION AND AMS ${ }^{14} \mathrm{C}$ ANALYSIS}

The same section of Pinus kesiya (DIK 235/1) which was employed for examining atmospheric ${ }^{14} \mathrm{C}$ over Thailand for the bomb pulse period (Hua et al. 2000) was used for this study. The cross-section DIK 235/1 with clear annual ring structure and secure cross-dating from AD 1916-1994 is shown in Figure 1. The 1994 ring is incomplete because the tree fell in the middle of the growing season. The outer rings, from AD 1944 onwards, are entirely sapwood and typically $2 \mathrm{~mm}$ wide. The sample location was Doi Inthanon National Park in northwestern Thailand at $19^{\circ} \mathrm{N}, 99^{\circ} \mathrm{E}$. The site is $\sim 1000 \mathrm{~m}$ above mean sea level.

\footnotetext{
${ }^{1}$ Australian Nuclear Science and Technology Organisation (ANSTO), PMB 1, Menai NSW 2234, Australia.

${ }^{2}$ Corresponding author. Email: qhx@ansto.gov.au.

${ }^{3}$ NWG Macintosh Centre for Quaternary Dating, Madsen Building F09, University of Sydney, NSW 2006, Australia.
}

(C) 2004 by the Arizona Board of Regents on behalf of the University of Arizona Proceedings of the 18th International Radiocarbon Conference, edited by N Beavan Athfield and R J Sparks RADIOCARBON, Vol 46, Nr 2, 2004, p 925-932 


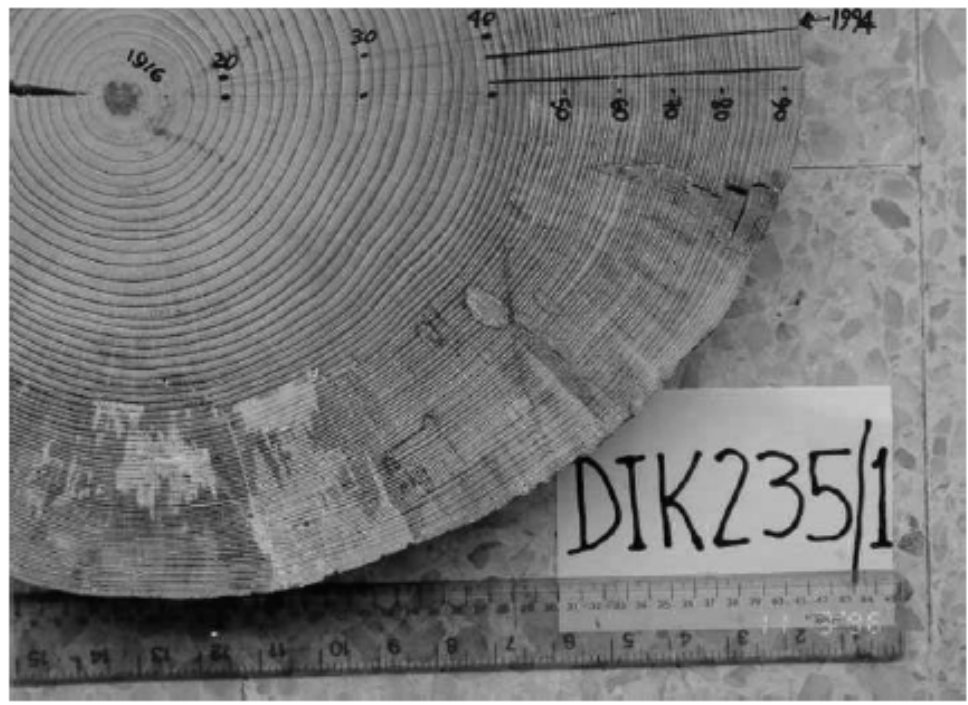

Figure 1 Cross-section of Thai Pinus kesiya DIK 235/1 with rings from AD 1916 to 1994, from which a sub-section was used for AMS ${ }^{14} \mathrm{C}$ analysis.

Pinus kesiya is one of very few tree species in the tropics with a clear annual ring structure. It has recently been used for dendroclimatic research due to strong cross-dating between trees from various sites in different regions in Thailand, including Doi Inthanon (Buckley et al. 1995; D'Arrigo et al. 1997). Moisture and temperature are 2 key parameters for the growth of Pinus kesiya. During the growing season (the rainy months from May to October), the air mass over the sampling site is from the Indian Ocean carried by the southwest Asian monsoon (Nieuwolt 1978).

Fourteen samples of single tree rings from $1938-1951$ were prepared for AMS ${ }^{14} \mathrm{C}$ analysis following the protocols developed by Hua et al. (1999). The samples were pretreated to alpha-cellulose using the method described in Hua et al. (2000). The pretreated material was combusted to $\mathrm{CO}_{2}$, then converted to graphite using methods described in Hua et al. (2001). AMS ${ }^{14} \mathrm{C}$ measurements were performed using the ANTARES facility at ANSTO (Lawson et al. 2000; Fink et al. 2004) with a precision of $0.25-0.3 \%$. The ${ }^{14} \mathrm{C} /{ }^{13} \mathrm{C}$ ratio of each sample was measured relative to the NIST standard of oxalic acid I (HOxI; Stuiver 1983). The $\Delta^{14} \mathrm{C}$ of each sample was calculated after correcting for (i) backgrounds (accelerator and chemistry), (ii) isotopic fractionation using measured $\delta^{13} \mathrm{C}$, and (iii) radioactive decay of both sample and standard. In addition, 2 annual rings, 1953-1954, which had been analyzed previously (Hua et al. 2000), were re-sampled and measured for this study (see below).

\section{AMS RESULTS AND DISCUSSION}

The AMS ${ }^{14} \mathrm{C}$ results for Thailand for ${ }^{1938-1951 ~ e x p r e s s e d ~ i n ~} \Delta{ }^{14} \mathrm{C}$ are presented in Table 1 and illustrated in Figure 2. $\Delta^{14} \mathrm{C}$ values for Arizona $\left(32^{\circ} \mathrm{N}, 111^{\circ} \mathrm{W}\right.$; Damon et al. 1989) and Washington $\left(48^{\circ} \mathrm{N}, 124^{\circ} \mathrm{W}\right.$; Stuiver et al. 1998) for the same period are also plotted in Figure 2 for comparison.

${ }^{14} \mathrm{C}$ offsets between Thailand and northern temperate regions for AD 1938-1951 are shown in Table 2. The difference between Washington and Thailand is $-0.7 \pm 0.9 \%$ (Thailand is higher). The offset between Arizona and Thailand is $2.4 \pm 0.8 \%$ (Thailand is lower). Note that when compared with Washington (1981 data; Stuiver and Quay 1981), Arizona is $\sim 2.5 \%$ higher for AD 1930-1954 
Table 1 Measured $\Delta^{14} \mathrm{C}$ from Pinus kesiya DIK-235/1 in Thailand $\left(19^{\circ} \mathrm{N}, 99^{\circ} \mathrm{E}\right)$.

\begin{tabular}{llll}
\hline $\begin{array}{l}\text { Ring formation } \\
\text { (year AD) }\end{array}$ & $\begin{array}{l}\text { Laboratory } \\
\text { code }\end{array}$ & $\begin{array}{l}\delta^{13} \mathrm{C} \\
(\%)\end{array}$ & $\begin{array}{l}\Delta^{14} \mathrm{C} \\
(\%)\end{array}$ \\
\hline 1938 & OZE647 & -25.1 & $-18.9 \pm 2.9$ \\
1939 & OZE648 & -25.4 & $-20.6 \pm 2.7$ \\
1940 & OZE649 & -24.5 & $-22.7 \pm 2.8$ \\
1941 & OZE650 & -24.8 & $-17.2 \pm 2.7$ \\
1942 & OZE651 & -26.3 & $-16.3 \pm 3.0$ \\
1943 & OZE652 & -26.1 & $-17.6 \pm 2.8$ \\
1944 & OZE653 & -25.4 & $-21.1 \pm 2.8$ \\
1945 & OZE654 & -25.7 & $-24.2 \pm 2.9$ \\
1946 & OZE655 & -26.6 & $-17.1 \pm 2.6$ \\
1947 & OZE656 & -27.0 & $-22.6 \pm 2.9$ \\
1948 & OZE657 & -26.0 & $-24.4 \pm 2.8$ \\
1949 & OZE658 & -26.0 & $-22.5 \pm 2.7$ \\
1950 & OZE659 & -25.1 & $-27.1 \pm 2.3$ \\
1951 & OZE660 & -25.5 & $-25.8 \pm 2.4$ \\
1952 & OZD107 & -25.7 & $-24.9 \pm 4.9^{\mathrm{a}}$ \\
1953 & OZD108U2 & -25.8 & $-23.5 \pm 3.5^{\mathrm{b}}$ \\
1954 & OZD109U2 & -25.4 & $-26.8 \pm 3.9^{\mathrm{b}}$ \\
\hline
\end{tabular}

aDatum reported in Hua et al. (2000).

${ }^{b}$ Data for 1953-1954 are now revised (this paper, cf. Hua et al. 2000).

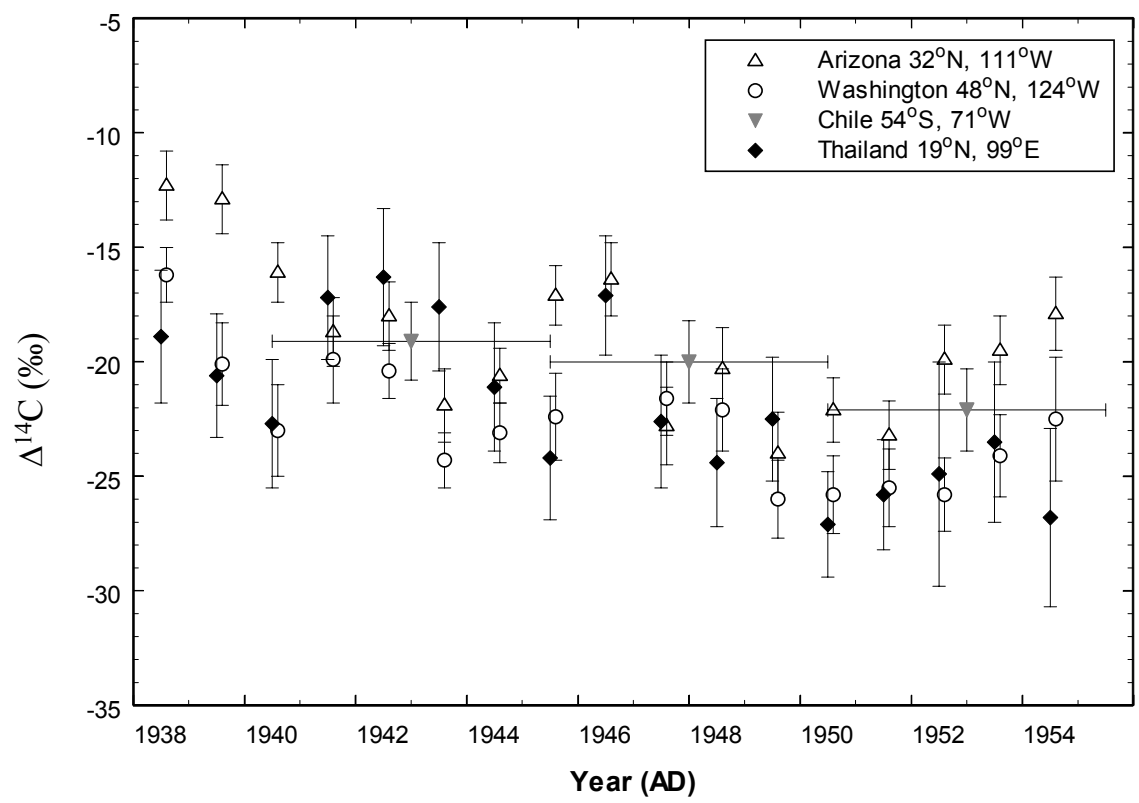

Figure 2 Measured $\Delta^{14} \mathrm{C}$ values for Thailand for AD 1938-1954 (from this study and Hua et al. 2000) compared with data for Arizona (Damon et al. 1989), Washington (Stuiver et al. 1998), and Chile (5ring samples; McCormac et al. 2002). 
(Damon et al. 1989). This offset becomes $3.4 \pm 0.5 \%$ when $\Delta{ }^{14} \mathrm{C}$ values for Arizona are compared to the revised Washington data (Stuiver et al. 1998). The depletion of Washington (relative to Arizona) for AD 1930-1954 was thought to be due to the oceanic upwelling of the North Pacific Ocean off the coast of Washington State (Damon et al. 1989). The results of this study show that on average, $\Delta{ }^{14} \mathrm{C}$ data for Thailand are not lower than those for Washington for AD 1938-1951 (see Table 2). This may imply a no-greater upwelling effect for the northern Indian Ocean (if it exists) compared to that for the North Pacific Ocean off the coast of Washington (see discussion below).

Table $2{ }^{14} \mathrm{C}$ offsets between northern temperate sites and Thailand $\left(19^{\circ} \mathrm{N}, 99^{\circ} \mathrm{E}\right)$ for AD 1938-1951 (14 yr) and AD 1938-1954 (17 yr). We used Arizona data from Damon et al. (1989) and Washington data from Stuiver et al. (1998).

\begin{tabular}{lll}
\hline Sites & $\begin{array}{l}\text { Offset relative to Thailand } \\
(\%)\end{array}$ & Periods (AD) \\
\hline Arizona & $2.4 \pm 0.8$ & $1938-1951$ \\
$\left(32^{\circ} \mathrm{N}, 111^{\circ} \mathrm{W}\right)$ & $2.8 \pm 0.8$ & $1938-1954$ \\
Washington & $-0.7 \pm 0.9$ & $1938-1951$ \\
$\left(48^{\circ} \mathrm{N}, 124^{\circ} \mathrm{W}\right)$ & $-0.6 \pm 0.8$ & $1938-1954$ \\
\hline
\end{tabular}

These AMS results for Thailand, which do not show further evidence of intermittent strong upwelling, led us to reexamine the 1953 and 1954 data points. Accordingly, these 2 rings were resampled from the same Pinus kesiya section (DIK 235/1), pretreated to alpha-cellulose, and measured by AMS ${ }^{14} \mathrm{C}$. The $\Delta^{14} \mathrm{C}$ values of the new measurements, which are also presented in Table 1, are $-23.5 \pm 3.5 \%$ and $-26.8 \pm 3.9 \%$ for 1953 and 1954, respectively. The new results (OZD108U2 and OZD109U2; Table 1) differ significantly from those of the first set $(-48.5 \pm 5.7 \%$ and $-40.8 \pm 5.5 \%$ for 1953 and 1954, respectively; Hua et al. 2000), and show no strong depletion. Given the absence of strong upwelling for the extended period 1938 to 1951 and a subsequent critical evaluation of the concept and likely extent of possible old $\mathrm{CO}_{2}$ effects downwind of oceanic upwelling localities (Manning et al. 2002), the repeat measurements of the 1953 and 1954 Pinus kesiya rings are preferably accepted. Possible reasons for the divergence in the first set of measurements include accidental contamination in the pretreatment and target preparation, and the result of some instability in the measurement system and the accelerator. Before the strongly negative $\Delta^{14} \mathrm{C}$ values were published, 2 additional graphite targets were prepared from the old pretreated materials of rings 1953 and 1954, and measured by AMS. Results similar to those of the first set of measurements were obtained. This suggests that the divergence in the first set of measurements was due to accidental contamination of the sample in pretreatment. The earlier measurement for AD 1952 (OZD107; Table 1) did not appear to be affected and was not repeated.

For the pre-bomb period AD 1938-1954, Thailand is $0.6 \pm 0.8 \%$ higher than Washington and $2.8 \pm 0.8 \%$ lower than Arizona (Table 2). Do these offsets imply an oceanic upwelling effect for Thailand similar to that for Washington? In order to answer this question, we have compared published ${ }^{14} \mathrm{C}$ data from Chile $\left(54^{\circ} \mathrm{S}, 71^{\circ} \mathrm{W}\right.$; Stuiver and Braziunas 1998; McCormac et al. 2002) with those for Arizona, Washington, and Thailand. Figure 2 also shows $\Delta^{14} \mathrm{C}$ values for annual tree rings from Thailand for 1952-1954 (with the new measurements for 1953 and 1954), together with those for Arizona and Washington for the same period. $\Delta^{14} \mathrm{C}$ values for 5-ring samples from Chile for $1940-1954$ are also included in Figure 2 for comparison. In order to compare ${ }^{14} \mathrm{C}$ data for Arizona, Washington, and Thailand with the 5-ring $\Delta^{14} \mathrm{C}$ values for Chile for the overlapping period 1940-1954, we calculated $\Delta^{14} \mathrm{C}$ values by averaging the relevant 5 annual data for these 
northern temperate and tropical sites. These calculated 5-ring $\Delta{ }^{14} \mathrm{C}$ data and measured $\Delta^{14} \mathrm{C}$ values for Chile are presented in Table 3. Although 5-ring $\Delta^{14} \mathrm{C}$ values calculated from 5 annual measurements and measured $\Delta^{14} \mathrm{C}$ values from 5-ring samples are not necessarily identical, the comparison of Arizona, Washington, and Thailand with Chile in Table 3 can give some qualitative indications of their offsets. ${ }^{14} \mathrm{C}$ offsets between northern temperate and tropical regions, and Chile for 1940-1954, are shown in Table 4.

Table 3 Comparison of 5 -ring $\Delta{ }^{14} \mathrm{C}$, northern temperate and tropical sites versus Chile for AD 1940-1954.

\begin{tabular}{|c|c|c|c|c|}
\hline $\begin{array}{l}\text { Periods } \\
\text { (AD) }\end{array}$ & $\begin{array}{l}\text { Arizona }^{\mathrm{a}} \\
32^{\circ} \mathrm{N}, 111^{\circ} \mathrm{W}\end{array}$ & $\begin{array}{l}\text { Washington } \\
48^{\circ} \mathrm{N}, 124^{\circ} \mathrm{W}\end{array}$ & $\begin{array}{l}\text { Thailand } \\
19^{\circ} \mathrm{N}, 99^{\circ} \mathrm{E}\end{array}$ & $\begin{array}{l}\text { Chile }^{\mathrm{d}} \\
54^{\circ} \mathrm{S}, 71^{\circ} \mathrm{W} \\
\end{array}$ \\
\hline $\begin{array}{l}1940-1944 \\
1945-1949 \\
1950-1954\end{array}$ & $\begin{array}{l}-19.0 \pm 0.6 \\
-19.6 \pm 0.7 \\
-20.6 \pm 0.7\end{array}$ & $\begin{array}{l}-22.3 \pm 0.6 \\
-23.0 \pm 0.9^{\mathrm{e}} \\
-25.1 \pm 0.8\end{array}$ & $\begin{array}{l}-19.0 \pm 1.3 \\
-22.0 \pm 1.2 \\
-25.9 \pm 1.3\end{array}$ & $\begin{array}{l}-19.1 \pm 1.7 \\
-20.0 \pm 1.8 \\
-22.1 \pm 1.8\end{array}$ \\
\hline
\end{tabular}

${ }^{a}$ Calculated from annual data of Damon et al. (1989).

${ }^{\mathrm{b} C a l c u l a t e d}$ from annual data of Stuiver et al. (1998).

${ }^{\mathrm{c}}$ Calculated from annual data of this study and Hua et al. (2000).

${ }^{\mathrm{d}}$ Data reported for 5-ring samples (McCormac et al. 2002).

eEstimated from 4 annual data (1945 and 1947-1949) as no data available for 1946.

Table $4{ }^{14} \mathrm{C}$ offsets between northern temperate and tropical regions, and Chile $\left(54^{\circ} \mathrm{S}, 71^{\circ} \mathrm{W}\right)$ for AD $1940-1954$.

\begin{tabular}{ll}
\hline Sites & $\begin{array}{l}\text { Offset relative to Chile } \\
(\%)\end{array}$ \\
\hline Arizona $\left(32^{\circ} \mathrm{N}, 111^{\circ} \mathrm{W}\right)$ & $0.6 \pm 1.1$ \\
Washington $\left(48^{\circ} \mathrm{N}, 124^{\circ} \mathrm{W}\right)$ & $-3.1 \pm 1.1$ \\
Thailand $\left(19^{\circ} \mathrm{N}, 99^{\circ} \mathrm{N}\right)$ & $-1.9 \pm 1.3$ \\
\hline
\end{tabular}

Figure 3 shows temporal variations in atmospheric $\Delta^{14} \mathrm{C}$ for Washington, Thailand, and Chile for the period AD 1600-1954. Washington data are from single-ring samples for 1600-1954 from Stuiver et al. (1998). Thai data are from decadal samples for 1620-1780 (Hua et al. 2004) and from annual samples for 1938-1954 (this study). Meanwhile, data for Chile are derived from 1- to 5-ring samples for 1670-1954 (McCormac et al. 2002). On average, up to AD 1915, the Washington-Chile offset in ${ }^{14} \mathrm{C}$ is positive due to a stronger air-sea exchange of $\mathrm{CO}_{2}$ in the Southern Hemisphere causing more ${ }^{14} \mathrm{C}$-depleted $\mathrm{CO}_{2}$ from the ocean to enter the southern atmosphere compared to the northern (Lerman et al. 1970; Stuiver and Braziunas 1998; McCormac et al. 1998). This north-south offset, however, is significantly reduced and becomes negative after 1915 due to the influence of anthropogenic $\mathrm{CO}_{2}$ free of ${ }^{14} \mathrm{C}$ entering the atmosphere predominantly in the Northern Hemisphere since the Industrial Revolution (the Suess effect; Suess 1955). The differences between Washington and Chile are $4.9 \pm 0.2 \%$ and $-1.8 \pm 0.7 \%$ for $\mathrm{AD} 1670-1915$ and 1916-1954, respectively (Table 5). For AD 1940-1954, a period in which Northern Hemispheric air is strongly influenced by anthropogenic $\mathrm{CO}_{2}$, the Washington-Chile offset is strongly negative $(-3.1 \pm 1.1 \%$, Table 4$)$. The Thailand-Chile offset for $\mathrm{AD} 1940-1954$ is also negative $(-1.9 \pm 1.3 \%$; Table 4$)$. This leaves a $-1.2 \pm 1.7 \%$ o difference between Washington and Thailand with Thailand higher for 1940-1954. The WashingtonThailand offset follows the trend of the inter-hemispheric offset (Washington-Chile), as it is $2.4 \pm 0.7 \%$ for $1620-1780$ (Hua et al. 2004), then decreases and reverses to about $-1.2 \pm 1.7 \%$ for 1940-1954 (see Figure 3). These results indicate that Thailand follows the trend of the Southern Hemisphere. This supports our previous interpretation that during the latter part of the Little Ice Age 
(LIA), the air mass in Thailand during the growing season of tree rings was strongly influenced by the entrainment of Southern Hemisphere air parcels during the southwest Asian monsoon, when the Inter-Tropical Convergence Zone moves to the north of our sampling site (Hua et al. 2004). This implies that for Thailand, the effect of regional oceanic upwelling in the northern Indian Ocean must be small compared to the influence of Southern Hemisphere air during the southwest monsoon.

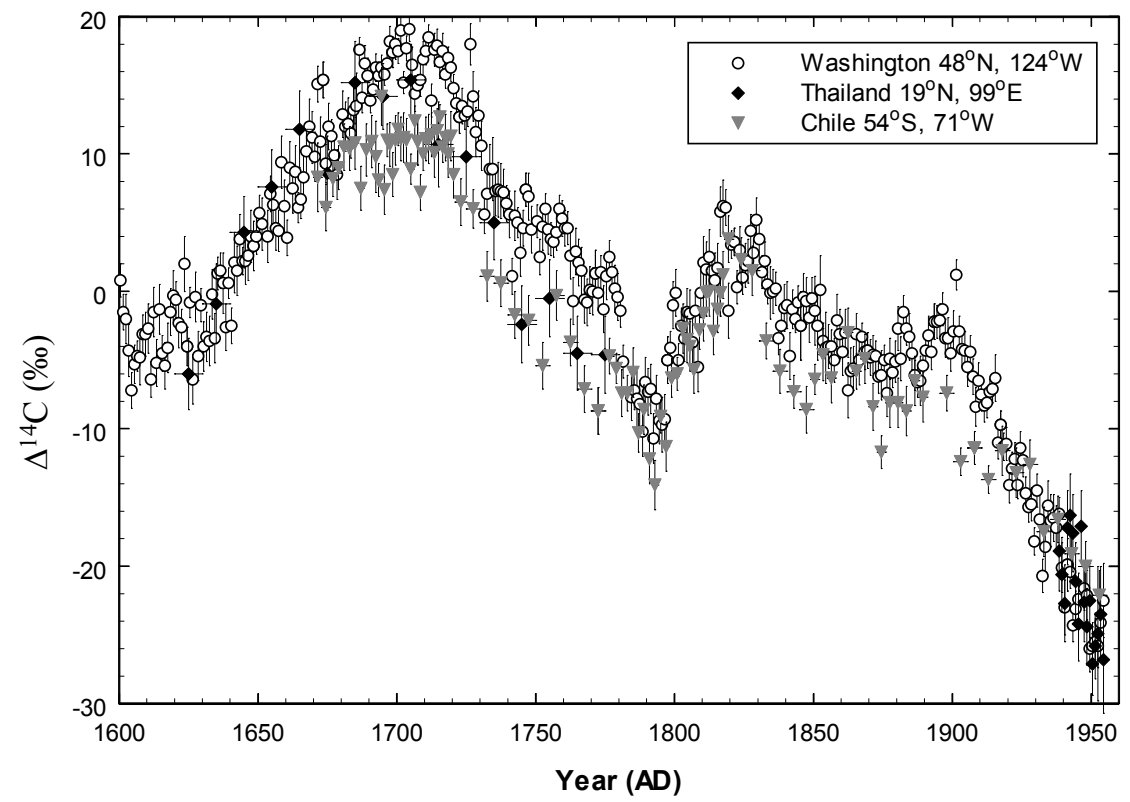

Figure 3 Temporal variations in atmospheric $\Delta^{14} \mathrm{C}$ for Washington, Thailand, and Chile for $\mathrm{AD}$ 1600-1954. Data are from annual samples for Washington (Stuiver et al. 1998), 1- to 5-ring samples for Chile for 1670-1954 (McCormac et al. 2002), decadal samples for Thailand for 1620-1780 (Hua et al. 2004), and annual samples for 1938-1954 (this study), respectively.

Table $5{ }^{14} \mathrm{C}$ offsets between Washington $\left(48^{\circ} \mathrm{N}, 124^{\circ} \mathrm{W}\right)$ and Chile $\left(54^{\circ} \mathrm{S}, 71^{\circ} \mathrm{W}\right)$ for $\mathrm{AD} 1670$ to 1954. Note: ${ }^{14} \mathrm{C}$ offset for each period of time was an error-weighted mean of the offsets between calculated $n$-ring $\Delta^{14} \mathrm{C}$ values from Washington annual data (Stuiver et al. 1998) and measured n-ring $\Delta^{14} \mathrm{C}$ values from Chile (McCormac et al. 2002). Note that $n$ varies from 1 to 5 .

\begin{tabular}{ll}
\hline & Washington-Chile offset \\
Periods (AD) & $(\%)$ \\
\hline $1670-1915$ & $4.9 \pm 0.2$ \\
$1916-1954$ & $-1.8 \pm 0.7$ \\
\hline
\end{tabular}

\section{CONCLUSION}

Seventeen annual tree rings from Thailand from AD 1938-1954 have now been analyzed by AMS. The results showed no significant depletion in ${ }^{14} \mathrm{C}$ over Thailand during the pre-bomb period, even though the air mass to Thailand during the growing season of tree rings is transported over a potentially significant source of oceanic ${ }^{14} \mathrm{C}$-depleted $\mathrm{CO}_{2}$, outgassing in the northern Indian Ocean. 
Anthropogenic $\mathrm{CO}_{2}$ free of ${ }^{14} \mathrm{C}$ has been introduced to the atmosphere due to the combustion of fossil fuel and land clearing, predominantly in the Northern Hemisphere, since the Industrial Revolution. As a result, the Washington-Chile offset was positive for 1670-1915, then decreased and became negative for 1916-1954. The Washington-Thailand offset follows that trend as the offset becomes smaller and reverses to a negative value $(-1.2 \pm 1.7 \%$ ) for $1940-1954$ from a measured value of $2.4 \pm 0.7 \%$ for $\mathrm{AD} 1620-1780$. These results indicate that Thailand has the characteristic of Southern Hemisphere ${ }^{14} \mathrm{C}$ and, hence, support our interpretation that Thailand was strongly influenced by the entrainment of Southern Hemisphere air parcels in the southwest Asian monsoon during the latter part of the LIA (Hua et al. 2004) and the pre-bomb period, AD 1938-1954. These results also imply that the effect of the reduction of atmospheric ${ }^{14} \mathrm{C}$ over Thailand in association with upwelling in the northern Indian Ocean must be small compared to the influence of Southern Hemisphere air over Thailand during the southwest monsoon.

\section{ACKNOWLEDGEMENTS}

The authors wish to thank P J Krusic, B M Buckley, and R D D'Arrigo (Lamont-Doherty Earth Observatory), and M Watanasak, S Boonchirdchoo, and S Sarutanon (Mahidol University) for their efforts in dendrochronology of Pinus kesiya. Mrs A M Macintosh has provided generous financial support for the NWG Macintosh Centre since 1982. We also thank other members of the AMS project (ANSTO) for helping with sample preparation and ${ }^{14} \mathrm{C}$ measurements. We gratefully acknowledge funding from the Australian Institute of Nuclear Science and Engineering (AINSE) for AMS ${ }^{14} \mathrm{C}$ measurements (grant 00/004).

\section{REFERENCES}

Buckley BM, Barbetti M, Watanasak M, D'Arrigo R, Boonchirdchoo S, Sarutanon S. 1995. Dendrochronological investigations in Thailand. IAWA Journal 16(4):393-409.

Damon PE, Cheng S, Linick TW. 1989. Fine and hyperfine structure in the spectrum of secular variations of atmospheric ${ }^{14}$ C. Radiocarbon 31(3):704-18.

D'Arrigo RD, Barbetti M, Watanasak M, Buckley BM, Krusic P, Boonchirdchoo S, Sarutanon S. 1997. Progress in dendroclimatic studies of mountain pine in northern Thailand. IAWA Journal 18(4):433-44.

Dutta K, Bhushan K, Somayajulu BLK. 2001. $\Delta$ R correction values for the northern Indian Ocean. Radiocarbon 43(2A):483-8.

Fink D, Hotchkis MAC, Hua Q, Jacobsen GE, Smith AM, Zoppi U, Child D, Mifsud C, van der Gaast HA, Williams AA, Williams M. Forthcoming. The ANTARES AMS Facility at ANSTO. Nuclear Instruments and Methods in Physics Research B.

Hua Q, Barbetti M, Worbes M, Head J, Levchenko VA. 1999. Review of radiocarbon data from atmospheric and tree ring samples for the period 1945-1997 AD. IAWA Journal 20(3):261-83.

Hua Q, Barbetti M, Jacobsen GE, Zoppi U, Lawson EM. 2000. Bomb radiocarbon in annual tree rings from Thailand and Tasmania. Nuclear Instruments and Methods in Physics Research B 172:359-65.

Hua Q, Jacobsen GE, Zoppi U, Lawson EM, Williams AA, Smith AM, McGann MJ. 2001. Progress in radio- carbon target preparation at the ANTARES AMS Centre. Radiocarbon 43(2A):275-82.

Hua Q, Barbetti M, Zoppi U, Fink D, Watanasak M, Jacobsen GE. Forthcoming. Radiocarbon in tropical tree rings during the Little Ice Age. Nuclear Instruments and Methods in Physics Research B.

Keeling CD. 1968. Carbon dioxide in surface ocean waters 4. Global distribution of $\mathrm{pCO}_{2}$. Journal of Geophysical Research 73:4543-53.

Lawson EM, Elliott G, Fallon J, Fink D, Hotchkis MAC, Hua Q, Jacobsen GE, Lee P, Smith AM, Tuniz C, Zoppi U. 2000. AMS at ANTARES-the first 10 years. Nuclear Instruments and Methods in Physics Research B 172:95-9.

Lerman JC, Mook WG, Vogel JC. 1970. C14 in tree rings from different localities. In: Olsson IU, editor. Radiocarbon Variations and Absolute Chronology. Proceedings, XII Nobel Symposium. New York: Wiley. p 275-301.

Manning SW, Barbetti M, Kromer B, Kuniholm PI, Levin I, Newton MW, Reimer PJ. 2002. No systematic early bias to Mediterranean ${ }^{14} \mathrm{C}$ ages: radiocarbon measurements from tree-ring and air samples provide tight limits to age offsets. Radiocarbon 44(3):739-54.

McCormac FG, Hogg AG, Higham TFG, Lynch-Stieglitz J, Broecker WS, Baillie MGL, Palmer J, Xiong L, Pilcher JR, Brown D, Hoper ST. 1998. Temporal variation in the interhemispheric ${ }^{14} \mathrm{C}$ offset. Geophysical Research Letters 25(9):1321-4. 
McCormac FG, Reimer PJ, Hogg AG, Highham TFG, Baillie MGL, Palmer J, Stuiver M. 2002. Calibration of radiocarbon timescale for the Southern Hemisphere: AD 1850-950. Radiocarbon 44(3):641-51.

Nieuwolt S. 1978. Tropical Climatology-An Introduction to the Climates of the Low Latitudes. Chichester: John Wiley \& Sons.

Southon J, Kashgarian M, Fontugne M, Metivier B, Yim W. 2002. Marine reservoir corrections for the Indian Ocean and Southeast Asia. Radiocarbon 44(1):16780.

Stuiver M. 1983. Business meeting: international agreements and the use of the new oxalic acid standard. Radiocarbon 25(2):793-5.

Stuiver M, Braziunas TF. 1998. Anthropogenic and solar components of hemispheric ${ }^{14} \mathrm{C}$. Geophysical Research Letters 25(3):329-32.
Stuiver M, Östlund HG. 1983. GEOSECS Indian Ocean and Mediterranean radiocarbon. Radiocarbon 25(1): $1-29$.

Stuiver M, Quay PD. 1981. Atmospheric ${ }^{14} \mathrm{C}$ changes resulting from fossil fuel $\mathrm{CO}_{2}$ release and cosmic ray flux variability. Earth and Planetary Science Letters 53:349-62.

Stuiver M, Reimer PJ, Braziunas TF. 1998. Radiocarbon age calibration for terrestrial and marine samples. Radiocarbon 40(3):1127-51.

Suess HE. 1955. Radiocarbon concentration in modern wood. Science 122:415-7.

Takahashi T, Feely RA, Weiss RF, Wanninkhof RH, Chipman DW, Sutherland SC, Takahashi TT. 1997. Global air-sea flux of $\mathrm{CO}_{2}$ : an estimate based on measurements of sea-air $\mathrm{CO}_{2}$ difference. Proceedings of the National Academy of Sciences USA 94:8292-9. 